\title{
Peningkatan Aktivitas Enzim Selulase dan Produksi Glukosa Melalui Fermentasi Substrat Jerami Padi Dengan Fungi Aspergillus niger yang Dipapari Sinar Gamma
}

\section{Enhanced Cellulase Enzyme Activity and Glucose Production through Fermentation Using Rice Straw Substrate With Gamma Ray Exposed-Aspergillus niger}

\author{
Nana Mulyana ${ }^{1}$, Tri Retno Dyah Larasati ${ }^{1}$, Nurhasni ${ }^{2}$ dan Meliana \\ Ningrum ${ }^{2}$ \\ ${ }^{1}$ Pusat Aplikasi Isotop dan Radiasi, BATAN \\ Jl. Lebak Bulus Raya No. 49 Jakarta Selatan 12440 \\ ${ }^{2}$ Fakultas Sains dan Teknologi, UIN Syarif Hidayatullah Jakarta \\ Jl. Ir. H. Juanda No. 95 Ciputat Jakarta \\ Email : nanamulyana@batan.go.id
}

Diterima 06-02-2015; Diterima dengan revisi 17-02-2015; Disetujui 15-04-2015

\begin{abstract}
ABSTRAK
Peningkatan Aktivitas Enzim Selulase dan Produksi Glukosa Melalui Fermentasi Substrat Jerami Padi Dengan Fungi Aspergillus niger yang Dipapari Sinar Gamma. Penelitian ini bertujuan untuk meningkatkan aktivitas enzim selulase dan produksi glukosa dalam substrat jerami padi dengan fungi Aspergillus niger yang dipapari sinar gamma Chamber 4000A. Kaldu kentang dektrosa (PDB), garam mineral dengan substrat jerami padi 0 dan 5\% berat/volum digunakan sebagai medium cair. Fungi Aspergillus niger dalam media agar miring (slent) dipapari dengan iradiasi gamma pada dosis 0 (kontrol),125, 250, 375, 500 dan $625 \mathrm{~Gy}$. Fungi Aspergillus niger yang dipapari sinar gamma $500 \mathrm{~Gy}$ memiliki aktivitas selulase lebih tinggi $(2,5$ kali) dibanding kontrol (0 Gy) yaitu 2,02 U/ml-2,28 U/ml untuk fungi yang dipapari iradiasi gamma dan 0,60 U/ml-1,12 U/ml untuk kontrol. Pada fermentasi fase padat substrat jerami padi dengan kadar kelembaban awal $81 \%$ selama 14 hari menggunakan fungi Aspergillus niger yang dipapari sinar gamma 500 Gy dan kontrol. Hasilnya menunjukkan bahwa fungi Aspergillus niger 500 Gy memiliki aktivitas selulase lebih tinggi $(3,9$ kali) dibandingkan kontrol yaitu 31,01 U/g untuk fungi yang dipapari sinar gamma dan 7,85 U/g untuk kontrol. Di samping itu, fungi Aspergillus niger (500 Gy) mampu memproduksi glukosa lebih tinggi $(2,6$ kali) yaitu $125,79 \mathrm{mg} / \mathrm{g}$ sedangkan kontrol (0 Gy) adalah 48,00 mg/g. Penggunaan ekstrak enzim kasar yang dihasilkan oleh fungi Aspergillus niger yang dipapar sinar gamma 500 Gy sesuai untuk hidrolisis substrat jerami padi dalam memproduksi glukosa serta mampu meningkatkan aktivitas selulase.
\end{abstract}

Kata kunci : Aspergillus niger, iradiasi gamma, aktivitas selulase, glukosa, fermentasi padat

\begin{abstract}
Enhanced Cellulase Enzyme Activity and Glucose Production through Fermentation Using Rice Straw Substrate With Gamma Ray Exposed-Aspergillus niger. This research aims to improve the activity of cellulase and glucose production in rice straw substrate with fungal Aspergillus niger exposed by gamma rays of 4000A Gamma Chamber. Potatoes Dextrose Broth (PDB), salt mineral with substrate of $0 \%$ and $5 \% \mathrm{w} / \mathrm{v}$ rice straw were used as liquid medium. Fungi Aspergillus niger in a medium slent was exposed by gamma irradiation doses at 0 (control), 125, 250,375, 500 and 625 Gray. The result indicates that fungal Aspergillus niger exposed by gamma rays dose at $500 \mathrm{~Gy}$ has higher cellulase activity (2.5 times) than control, i.e $2.02 \mathrm{U} / \mathrm{ml}-2.28 \mathrm{U} / \mathrm{ml}$ and $0.60 \mathrm{U} / \mathrm{ml}-1.12 \mathrm{U} / \mathrm{ml}$, respectively. The solid state fermentation of rice straw was conducted using fungal Aspergillus niger (500 Gy dose) with $81 \%$ moisture content for 14 days. The result indicates that fungal
\end{abstract}




\begin{abstract}
Aspergillus niger (500 Gy dose) has higher cellulase activity is 3.91 times than that of the control, i.e $31.01 \mathrm{U} / \mathrm{g}$ and $7.85 \mathrm{U} / \mathrm{g}$, respectively. Meanwhile, fungal Aspergillus niger (500 Gy dose) has glucose production 2.62 times above control, i.e $125.79 \mathrm{mg} / \mathrm{g}$ and $48.00 \mathrm{mg} / \mathrm{g}$, respectively. Crude enzyme produced by fungal Aspergillus niger (500 Gy dose) is approriate to be used as hydrolize substrate of rice straw, to produce glucose and to enhance cellulase activity.
\end{abstract}

Keys word: Aspergillus niger, gamma irradiation, cellulase activity, glucose, solid fermentation

\section{PENDAHULUAN}

Biomassa selulosa merupakan molekul organik yang paling melimpah di bumi dan terus diisi ulang oleh fiksasi karbon dioksida melalui fotosintesis [1]. Semua bahan selulosa, termasuk limbah agro-industri dapat dikonversi menjadi produk komersial penting seperti etanol, metana, sirup glukosa dan protein sel tunggal [2]. Pengembangan proses industri untuk biokonversi selulosa akan membantu meringankan kekurangan dalam pakan hewan dan mengurangi masalah pembuangan limbah perkotaan dan ketergantungan pada bahan bakar fosil [3]. Sukses pemanfaatan sumber daya terbarukan tergantung pada pengembangan proses ekonomis yang mencakup produksi enzim selulase yang diperlukan untuk hidrolisis enzimatik bahan selulosa [1]. Selulase merupakan enzim penting dalam industri yang digunakan pada pengolahan pati, produksi pakan ternak, bahan bakar, bahan kimia, pulp, kertas, tekstil, industri farmasi, sakarifikasi limbah organik pertanian dan pengembangan teknologi bioetanol $[4,5,6,7,8,9]$.

Enzim selulase diperoleh melalui fermentasi bahan organik dengan spesies fungi seperti Trichoderma, Penicillium dan Aspergillus spp. $[6,10,11]$. Produksi enzim selulase juga sering menggunakan spesies bakteri seperti Pseudomonas, Cellulomonas, Bacillus, Micrococcus, Cellovibrio dan Sporosphytophaga spp. [12]. Namun, fungi berfilamen lebih disukai untuk produksi enzim secara komersial karena memiliki kemampuan yang lebih tinggi dibandingkan ragi dan bakteri [13]. Penggunaan fungi juga dipandang lebih menguntungkan karena sebagian besar enzim yang dihasilkan bersifat ekstraselular sehingga lebih mudah dalam ditangani dalam proses hilir produksi enzim ini [14].

Penggunaan fungi Aspergillus niger pada produksi enzim selulase telah digunakan di seluruh dunia [14]. Fungi Aspergillus niger memanfaatkan selulosa dan menghasilkan enzim selulase bebas sel yang mampu menghidrolisis selulosa menjadi gula mudah larut seperti glukosa yang merupakan bahan baku penting dalam industri kimia [14]. Fungi Aspergillus niger dapat digunakan untuk produksi enzim selulase melalui fermentasi terendam (submerged) dan padat (solid-state). Aktivitas enzim selulase fungi Aspergillus niger dalam medium fermentasi terendam sekitar 3,29 $\mathrm{U} / \mathrm{ml}$ dan dalam medium fermentasi padat sekitar 8,89 U/g. Produktivitas selulase ekstraselular fungi Aspergillus niger pada fermentasi padat sekitar 14,60 kali lipat lebih tinggi dibanding fermentasi terendam [15]. Selain meningkatkan hasil, fermentasi padat dapat menurunkan biaya produksi enzim [16].

Produksi enzim selulase melalui fermentasi padat substrat limbah pertanian telah banyak dilakukan untuk menurunkan biaya produksi dan memperoleh enzim yang ekonomis $[5,17,18]$. Pemanfaaatan substrat murah dan peningkatan produktivitas enzim tetap merupakan obyek penting dalam penelitian. Pengembangan kuantitas dan kualitas produk enzim selulase diperlukan untuk memenuhi kebutuhan enzim selulase di berbagai bidang yang terus meningkat secara eksponensial. Upaya meningkatkan produksi enzim melalui seleksi dan optimasi media dengan strain fungi tipe liar (wild types) masih belum optimal [19]. Contoh sukses yang spektakular adalah perbaikan 
strain dalam industri yang sebagian besar terkait dengan aplikasi mutasi dan seleksi $[8,9]$. Perbaikan strain fungi tersebut dapat menurunkan biaya produksi, meningkatkan produktivitas dan karakteristik produk yang sesuai dengan harapan [14].

Pada penelitian terdahulu telah dilakukan upaya peningkatan produksi enzim selulase dari fungi Chaetomium cellulyticum melalui mutasi dan optimasi fermentasi padat substrat bagas tebu [20]. Fungi Chaetomium cellulyticum yang dipapari sinar gamma 500 Gray menunjukkan produksi enzim selulase yang lebih tinggi sekitar 1,45 kali lipat dibandingkan tipe liarnya (wild types) yaitu fungi yang tidak dipapari sinar gamma [20]. Aktivitas enzim selulase fungi Chaetomium cellulyticum yang dipapari sinar gamma 500 Gray dan tipe liarnya (wild types) yiatu 29,20 U/g untuk fungi yang dipapari sinar gamma dan 20,10 U/g untuk tipe liarnya. Di sisi lain, fungi Chaetomium cellulyticum belum dikenal luas sedangan fungi Aspergillus niger merupakan fungi selulolitik yang terkenal dan bayak digunakan sebagai produsen enzim selulase [21]. Penelitian ini bertujuan untuk meningkatkan aktivitas selulase dan produksi glukosa dalam substrat jerami padi dengan fungi Aspergillus niger yang dipapar sinar gamma.

\section{BAHAN DAN METODE}

\section{Bahan dan peralatan}

Bahan-bahan yang digunakan terdiri dari media kultur fungi Aspergillus niger, jerami padi, PDB (potatoes dextrose broth), PDA (potatoes dextrose agar), larutan $1 \% \mathrm{NaOH}$ dan $1 \% \mathrm{H}_{2} \mathrm{SO}_{4}$, yeast ekstrak, $\left(\mathrm{NH}_{4}\right)_{2} \mathrm{SO}_{4}, \quad \mathrm{KH}_{2} \mathrm{PO}_{4}, \mathrm{~K}_{2} \mathrm{HPO}_{4}, \quad \mathrm{MgSO}_{4} .7 \mathrm{H}_{2} \mathrm{O}$, air fisiologis $(0,85 \% \mathrm{NaCl})$, larutan $1 \% \mathrm{CMC}$ (carboxymethyl-cellulase), bufer sitrat $(50 \mathrm{mM}$, $\mathrm{pH} 5,0)$, larutan DNS (dinitrosalicylic-acid), larutan Nelson dan arsenomolybdat. Peralatan yang digunakan meliputi tabung slent, cawan petri, erlemmeyer, gelas reaktor ukuran $500 \mathrm{ml}$, incubator (Heraeus), water bath, oven $105{ }^{\circ} \mathrm{C}$, tanur $650{ }^{\circ} \mathrm{C}$, desikator, microcentrifuge (Sorvall), centrifuge Himac CR21GII (Hitachi), autoclave (WiseClave), shaker (Edmund Buhler SR25), chopper mekanis, cutting mill, spektrofotometer serta fasilitas irradiator Gamma Chamber 4000A dengan sumber ${ }^{60} \mathrm{Co}$.

\section{Perlakuan iradiasi gamma}

Strain fungi Aspergillus niger diperoleh dari koleksi kultur terseleksi di Laboratorium Bidang Industri dan Lingkungan, Pusat Aplikasi Isotop dan Radiasi. Strain fungi tersebut dipelihara dalam tabung slent dengan media PDA pada $4{ }^{\circ} \mathrm{C}$. Kultur fungi Aspergillus niger yang berumur 7 hari dipapari sinar gamma pada dosis 0 (kontrol), 125, 250, 375, 500 dan 625 Gray. Iradiasi gamma menggunakan sumber ${ }^{60} \mathrm{Co}$ dilakukan di fasilitas iradiator Gamma Chamber 4000A, Pusat Aplikasi Isotop dan Radiasi, Badan Tenaga Nuklir Nasional.

\section{Preparasi substrat jerami padi}

Jerami padi (Oryza sativa L.) dari varietas Impari Sidenuk diperoleh dari petak sawah produksi bibit padi di Pusat Aplikasi Isotop dan Radiasi, BATAN. Jerami padi dikeringkan dan dicacah dengan chopper mekanis, kemudian dihaluskan dengan cutting mill dan diayak sehingga diperoleh substrat jerami padi dengan ukuran partikel $<2 \mathrm{~mm}[22,23]$. Ke dalam $2 \mathrm{~kg}$ substrat jerami padi ditambahkan 20 liter larutan $1 \% \mathrm{NaOH}$, diaduk secara merata dan dibiarkan selama 1-2 jam kemudian dilakukan pencucian sebanyak 3 kali dengan air mengalir dan dikeringkan dalam oven pada $40{ }^{\circ} \mathrm{C}$ sampai diperoleh berat yang konstan $[15,24]$. Hasil preparasi substrat ini berupa serbuk jerami padi dengan kadar air sekitar 10,26\%, C organik 25,91\%, selulosa $35,65 \%$ dan total $\mathrm{N} 1,34 \%$.

\section{Kultivasi fungi Aspergillus niger yang dipapar sinar gamma}

Fungi Aspergillus niger yang dipapari sinar gamma pada dosis 0 (kontrol), 125, $250,375,500$ dan 625 Gray dikultivasi dalam medium nutrisi garam mineral dengan substrat jerami padi 0 dan $5 \%(\mathrm{~b} / \mathrm{v})$. 
Setiap liter larutan nutrisi garam mineral tersebut mengandung $24 \mathrm{~g} \mathrm{PDB}, 5 \mathrm{~g}$ yeast ekstrak, $1 \mathrm{~g}\left(\mathrm{NH}_{4}\right)_{2} \mathrm{SO}_{4}, 0,5 \mathrm{~g} \mathrm{K \textrm {KH } _ { 2 }} \mathrm{PO}_{4}, 0,5 \mathrm{~g}$ $\mathrm{K}_{2} \mathrm{HPO}_{4}$ dan $0,2 \mathrm{~g} \quad \mathrm{MgSO}_{4} \cdot 7 \mathrm{H}_{2} \mathrm{O} \quad[25,26]$. Sebanyak $1 \mathrm{ml}$ kultur fungi Aspergillus niger dengan kerapatan $10^{6}$ propagul $/ \mathrm{ml}$ diinokulasikan ke dalam $50 \mathrm{ml}$ medium steril kemudian diinkubasi dalam shaker mekanis pada $100 \mathrm{rpm}$ dan suhu ruang sekitar $28-32{ }^{\circ} \mathrm{C}$ selama 4 hari.

\section{Fermentasi padat substrat jerami padi}

Perlakuan fermentasi padat substrat jerami padi dengan fungi Aspergillus niger terdiri dari $A_{1} M_{1}, A_{1} M_{2}, A_{1} M_{3}, A_{2} M_{1}, A_{2} M_{2}$ dan $\mathrm{A}_{2} \mathrm{M}_{3}$. Kultur fungi Aspergillus niger 0 Gray $\left(\mathrm{A}_{1}\right)$ dan 500 Gray $\left(\mathrm{A}_{2}\right)$ digunakan pada fermentasi substrat jerami padi dengan kadar kelembaban awal sekitar $81 \%\left(\mathrm{M}_{1}\right)$, $84 \%\left(\mathrm{M}_{2}\right)$ dan $87 \%\left(\mathrm{M}_{3}\right)$. Semua medium fermentasi diperkaya dengan larutan nutrisi garam mineral dan disterilkan dengan autoclave pada $121{ }^{\circ} \mathrm{C}$ selama 15 menit. Dua ml kultur fungi Aspergillus niger dengan kerapatan sekitar $10^{6}$ propagul $/ \mathrm{ml}$ diinokulasikan ke dalam $40 \mathrm{~g}$ (berat kering) substrat jerami padi kemudian diinkubasi pada suhu ruang sekitar $28-32{ }^{\circ} \mathrm{C}$ selama 21 hari.

\section{Hidrolisis substrat jerami padi}

Ekstrak kasar enzim selulase diperoleh dari medium fermentasi padat substrat jerami padi dengan fungi Aspergillus niger. Ke dalam 3 g medium fermentasi ini ditambahkan $30 \mathrm{ml}$ larutan bufer sitrat (50 $\mathrm{mM}, \mathrm{pH} 5,0$ ) dan diagitasi dalam shaker mekanis pada $100 \mathrm{rpm}$ selama 1 jam, kemudian disentrifugasi pada $12000 \mathrm{rpm}$ dan $-4{ }^{\circ} \mathrm{C}$ selama 15 menit. Dua puluh $\mathrm{ml}$ ekstrak kasar enzim tersebut ditambahkan ke dalam 2 g substrat jerami padi steril kemudian diinkubasi dalam water bath pada $50{ }^{\circ} \mathrm{C}$ yang diagitasi dengan shaker mekanis pada $150 \mathrm{rpm}$ selama 2 hari [23].

\section{Penentuan aktivitas selulase dan kadar glukosa}

Penentuan aktivitas enzim selulase dengan substrat CMC (carboxymethyl- cellulase) dihitung berdasarkan estimasi gula reduksi yang dibebaskan dari reaksi ekstrak enzim dan CMC. Ke dalam campuran 500 $\mu 1 \mathrm{ml}$ larutan $1 \%$ CMC dan $500 \mu 1 \mathrm{ml}$ bufer sitrat $(50 \mathrm{mM}, \mathrm{pH} 5,0)$ ditambahkan $500 \mu 1$ $\mathrm{ml}$ ekstrak enzim kemudian diinkubasi dalam water bath pada $50{ }^{\circ} \mathrm{C}$ selama 30 menit dan penghentian reaksi dilakukan melalui penambahan $500 \mu \mathrm{l}$ larutan DNS. Larutan ini dipanaskan dalam air mendidih selama 5 menit dan didinginkan kemudian dilakukan pengukuran densitas optik dengan spektrofotometer pada $540 \mathrm{~nm}[28,30]$. Satu unit aktivitas selulase dihitung sebagai jumlah enzim yang diperlukan untuk melepaskan $1 \mu \mathrm{mol}$ gula reduksi/menit dengan standar glukosa [15].

Kadar glukosa sampel ditentukan dengan metode Nelson-Smogyi [30]. Ke dalam $500 \mu \mathrm{l}$ sampel ditambahkan $500 \mu \mathrm{l}$ larutan Nelson (campuran Nelson A dan B sekitar 25:1 v/v) dan dipanaskan pada 100 ${ }^{\circ} \mathrm{C}$ selama 20 menit, kemudian didinginkan dan ditambahkan $500 \quad \mu l$ larutan arsenomolibdat. Pengukuran densitas optik dilakukan dengan spektrofotometer pada $540 \mathrm{~nm}$. Kadar glukosa sampel dihitung berdasarkan nilai densitas optik (absorbansi) sesuai persamaan regresi larutan standar glukosa (kurva standar).

Pada penelitian ini juga dilakukan pengamatan $\mathrm{pH}$, viabilitas fungi, bobot biomassa mikroba, kadar air, kadar bahan organik, kadar $\mathrm{C}$ organik dan total $\mathrm{N}$. Pengukuran $\mathrm{pH}$ dilakukan dengan $\mathrm{pH}$ meter digital. Viabilitas fungi ditentukan dengan metode Total Plate Count dalam media PDA [26]. Bobot biomassa mikroba ditentukan secara gravimetri setelah pemisahan dengan sentrifuse pada $12000 \mathrm{rpm}$ selama 15 menit dan pengeringan dalam oven pada $60{ }^{\circ} \mathrm{C}$ selama 24 jam [27]. Kadar air ditentukan melalui pengeringan sampel dalam oven pada $105{ }^{\circ} \mathrm{C}$ selama 24 jam. Kadar bahan organik ditentukan melalui pemasan sampel dalam tanur pada $650{ }^{\circ} \mathrm{C}$ selam 5-6 jam. Analisis kadar C organik dan total N dilakukan di Laboratorium Kimia Universitas Nusa Bangsa, Bogor. 


\section{HASIL DAN PEMBAHASAN}

\section{Kultivasi fungi Aspergillus niger yang dipapar sinar gamma}

Setelah perlakuan iradiasi gamma pada dosis 125, 250, 375, 500 dan 625 Gray terjadi penurunan viabilitas fungi Aspergillus niger dari $7,83 \times 10^{7}$ propagul $/ \mathrm{ml}$ menjadi $5,93 \times 10^{7}$ sampai $8,00 \times 10^{6}$ propagul $/ \mathrm{ml}$. Peningkatan dosis iradiasi gamma dapat menurunkan jumlah organisme yang mampu bertahan hidup secara eksponensial [31]. Populasi fungi Aspergillus niger yang bertahan hidup setelah perlakuan iradiasi gamma, mampu tumbuh secara baik di dalam medium cair mengandung larutan nutrisi garam mineral serta substrat jerami padi 0 dan $5 \%$ berat/volum. Setelah 4 hari kultivasi dalam medium cair A (tanpa substrat jerami padi) dan B (substrat jerami padi $5 \% \mathrm{~b} / \mathrm{v}$ ), fungi Aspergillus niger yang dipapar sinar gamma 250, 375, 500 dan 625 Gray memiliki bobot biomassa yang lebih baik dibanding fungi Aspergillus niger tanpa perlakuan iradiasi gamma seperti disajikan pada Gambar 1. Peningkatan bobot biomassa fungi diperoleh pada kultivasi fungi Aspergillus niger yang dipapar sinar gamma mulai dari 250 sampai 500 Gray kemudian menurun pada kultivasi fungi Aspergillus niger yang dipapar sinar gamma 625 Gray. Hasil ini selaras dengan penelitian sebelumnya yang menunjukkan bahwa perlakuan iradiasi gamma pada dosis 200 sampai 500 Gray dapat meningkatkan bobot kering miselia isolat Aspergillus sp [32]. Fungi Aspergillus niger yang dipapar sinar gamma 500 Gray memiliki bobot biomassa yang optimal di dalam medium cair A dan B masing-masing sekitar 2,99 dan 4,31 $\mathrm{mg} / \mathrm{ml}$. Bobot biomassa fungi ini sekitar 1,99-2,41 kali lebih tinggi dibandingkan fungi Aspergillus niger tanpa perlakuan iradiasi gamma. Hal ini sesuai dengan penelitian S.A.Alting et.al (2015) yang menunjukkan bahwa Aspergillus niger yang diradiasi sinar gamma dengan dosis 400 Gy mendapatkan nilai D10 yang menghasilkan mutan superior. Nilai D10 merupakan radiosensitivity yakni dosis yang diperlukan untuk mengurangi viabilitas inokulum hingga $90 \%$ [33].

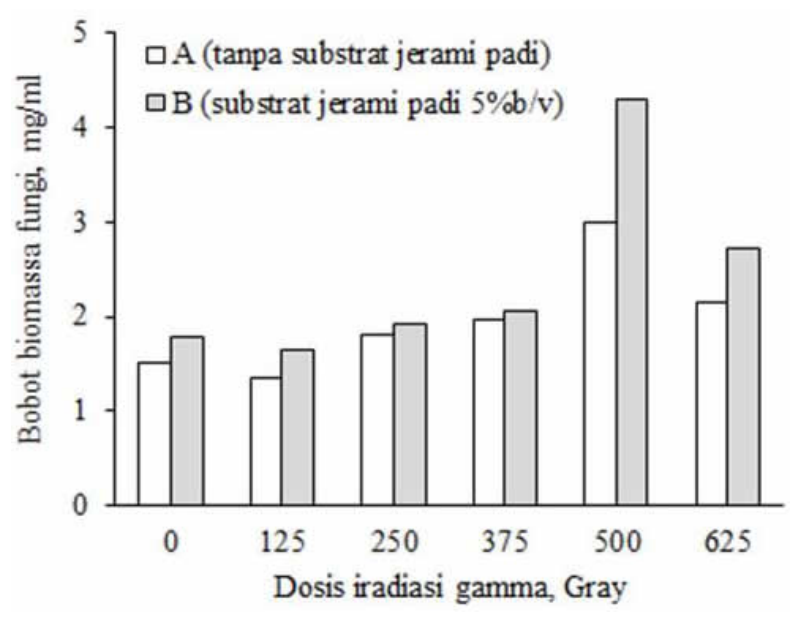

Gambar 1. Bobot biomassa fungi Aspergillus niger setelah 4 hari diinkubasi di dalam medium cair A dan B

Selain memiliki bobot biomassa yang optimal, fungi Aspergillus niger yang dipapar sinar gamma 500 Gray juga menunjukkan aktivitas selulase yang lebih tinggi dan berbeda nyata dibandingkan fungi Aspergillus niger tanpa perlakuan iradiasi gamma seperti disajikan pada Gambar 2. Di dalam medium cair A (tanpa substrat jerami padi) dan B (substrat jerami padi $5 \% \mathrm{~b} / \mathrm{v}$ ), fungi Aspergillus niger yang dipapar sinar gamma 500 Gray memiliki aktivitas selulase sekitar 2,02 dan 2,28 U/ml. Di dalam medium cair A dan B ini, fungi Aspergillus niger tanpa perlakuan iradiasi gamma memiliki aktivitas selulase sekitar 0,60 dan $1,12 \mathrm{U} / \mathrm{ml}$. Hasil ini menunjukkan bahwa di dalam medium cair A dan B, fungi Aspergillus niger yang dipapar sinar gamma 500 Gray mampu memberikan aktivitas selulase sekitar 1,04 dan 2,37 kali lebih tinggi dibanding fungi Aspergillus niger tanpa perlakuan iradiasi gamma. Ionisasi radiasi gamma dengan dosis relatif rendah dapat meningkatkan bobot biomassa, mengakselerasi aktivitas selulase dan protease beberapa strain fungi Aspergillus niger [34,35]. Hasil juga mengindikasikan bahwa fungi Aspergillus niger yang dipapar 
sinar gamma 500 Gray lebih berpotensi untuk digunakan dalam meningkatkan aktivitas selulase dan produksi glukosa pada fermentasi padat substrat jerami padi.

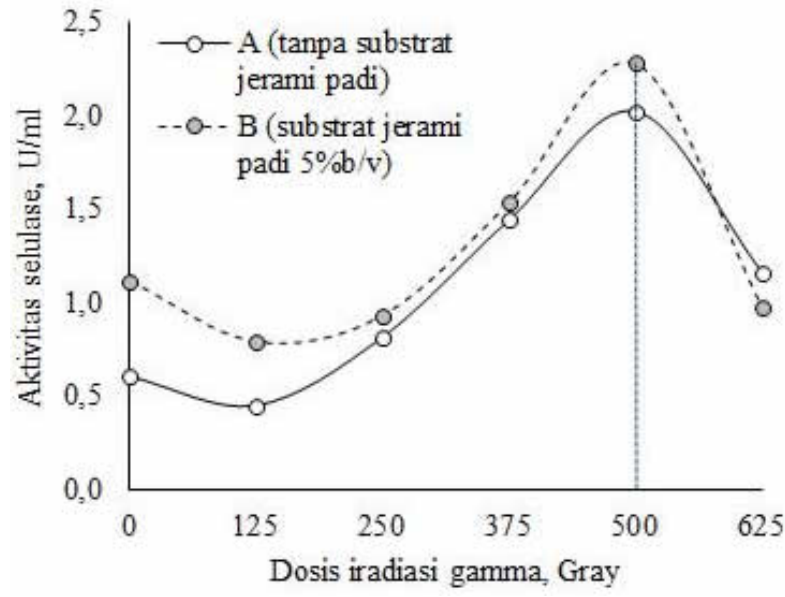

Gambar 2. Aktivitas selulase fungi Aspergillus niger setelah 4 hari diinkubasi di dalam medium cair A dan B

\section{Fermentasi Padat Substrat Jerami Padi}

Dalam fermentasi padat dengan fungi Aspergillus niger yang berlangsung selama 21 hari, terjadi perubahan $\mathrm{pH}$ medium substrat jerami padi seperti disajikan pada Gambar 3. Setelah 7 dan 14 hari fermentasi padat terjadi penurunan $\mathrm{pH}$ medium dari sekitar 6,65 - 6,79 menjadi 5,45 - 6,39. Nilai $\mathrm{pH}$ terendah diperoleh pada 14 hari fermentasi padat di dalam substrat jerami padi dengan kadar kelembaban awal $M_{1}(81 \%)$ yang diinokulasi fungi Aspergillus niger $\mathrm{A}_{2}$. Medium fermentasi ini memiliki $\mathrm{pH}$ sekitar 5,45 sedangkan medium perlakuan lain sekitar 5,99 - 6,39. Setelah 21 hari fermentasi padat, $\mathrm{pH}$ medium pada semua perlakuan kembali meningkat dari 5,45 6,39 menjadi 5,94 - 6,51. Perubahan $\mathrm{pH}$ medium dapat berpengaruh terhadap pertumbuhan mikroba, sekresi enzim dan kestabilan produk di dalam medium [15].

Gambar 4 menunjukkan bahwa selama fermentasi padat substrat jerami dengan kadar kelembaban awal $\mathrm{M}_{1}(81 \%)$, $\mathrm{M}_{2}(84 \%)$ dan $\mathrm{M}_{3}(87 \%)$ terjadi perubahan viabilitas baik fungi Aspergillus niger $\mathrm{A}_{1}(0$ Gray) maupun $A_{2}(500$ Gray). Di dalam semua medium substrat jerami padi, viabilitas fungi Aspergillus niger yang optimal diperoleh pada 14 hari fermentasi padat, yaitu sekitar $2,78 \times 10^{7}$ sampai $1,17 \times 10^{8}$ propagul/g. Hasil ini diduga terkait dengan $\mathrm{pH}$ medium fermentasi sekitar 5,45 - 6,39 yang sesuai untuk pertumbuhan fungi Aspergillus niger. Hal ini mengindikasikan bahwa fungi Aspergillus niger $\mathrm{A}_{1}(0 \quad \mathrm{~Gy})$ maupun $\mathrm{A}_{2}$ (500 Gy) dapat tumbuh secara baik di dalam medium fermentasi substrat

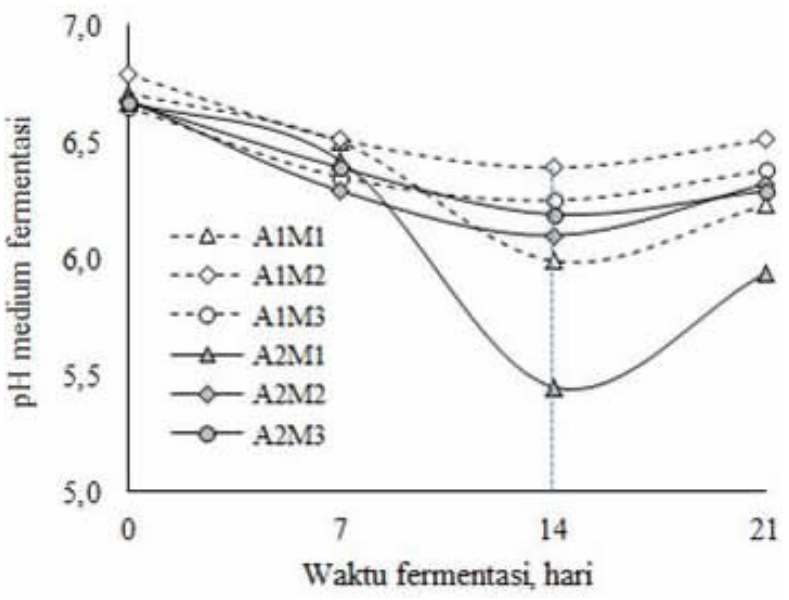

Gambar 3. Perubahan $\mathrm{pH}$ medium fermentasi padat dengan kadar kelembaban awal $\mathrm{M}_{1}(81 \%), \mathrm{M}_{2}$ (84\%) dan $\mathrm{M}_{3}$ (87\%) yang diinokulasi fungi A.niger $\mathrm{A}_{1}$ (0 Gray) dan $\mathrm{A}_{2}$ (500 Gray)

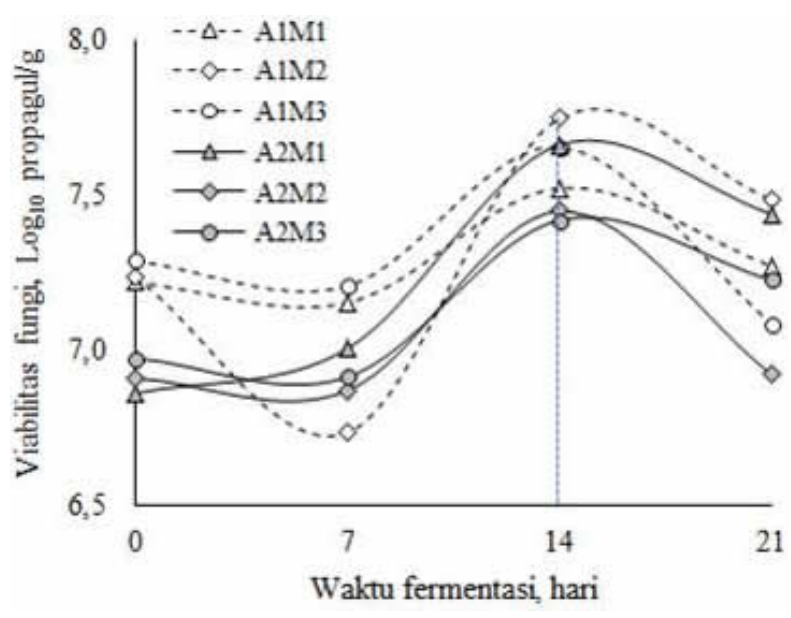

Gambar 4. Viabilitas fungi A.nigerA $A_{1}$ (0 Gray) dan $\mathrm{A}_{2}$ (500 Gray) di dalam substrat jerami dengan kadar kelembaban awal $M_{1}(81 \%), M_{2}(84 \%)$ dan $M_{3}$ $(87 \%)$ 
jerami padi dengan kadar awal sekitar $81 \%$ sampai $87 \%$. Hasil ini sesuai dengan peneliti terdahulu yang menunjukkan bahwa kelembaban awal sebesar $79 \%$ mampu menghasilkan aktivitas selulase optimal sebesar 96,44 U/g [33].

Pada 14 hari fermentasi padat substrat jerami $\mathrm{M}_{1}$ padi (81\%), fungi Aspergillus niger $\mathrm{A}_{1}$ (0 Gray) dan $\mathrm{A}_{2}$ (500 Gray) menunjukkan tampilan pertumbuhan relatif sama tetapi memiliki aktivitas selulase yang berbeda nyata seperti disajikan pada Gambar 5. Aktivitas selulase fungi Aspergillus niger $\mathrm{A}_{1}$ dan $\mathrm{A}_{2}$ sekitar 7,85 dan $31,01 \mathrm{U} / \mathrm{g}$. Di dalam medium jerami padi $\mathrm{M}_{2}(84 \%)$ dan $\mathrm{M}_{3}(87 \%)$, fungi Aspergillus niger $\mathrm{A}_{2} \quad(500$ Gray) memiliki aktivitas selulase sekitar 5,15 $7,19 \mathrm{U} / \mathrm{g}$ yang tidak berbeda nyata dengan aktivitas selulase fungi Aspergillus niger $\mathrm{A}_{1}(0$ Grayl di dalam semua perlakuan kadar kelembaban awal substrat jerami padi. Fungi Aspergillus niger tanpa perlakuan iradiasi gamma ini memiliki aktivitas selulase sekitar 5,20 - 7,85 U/g. Pada penelitian terdahulu diperoleh aktivitas selulase fungi Aspergillus niger maksimum dalam substrat dedak padi dengan metode fermentasi padat sekitar $8,89 \mathrm{U} / \mathrm{g}$ [15]. Dengan demikian, aktivitas selulase maksimum dapat diperoleh melalui

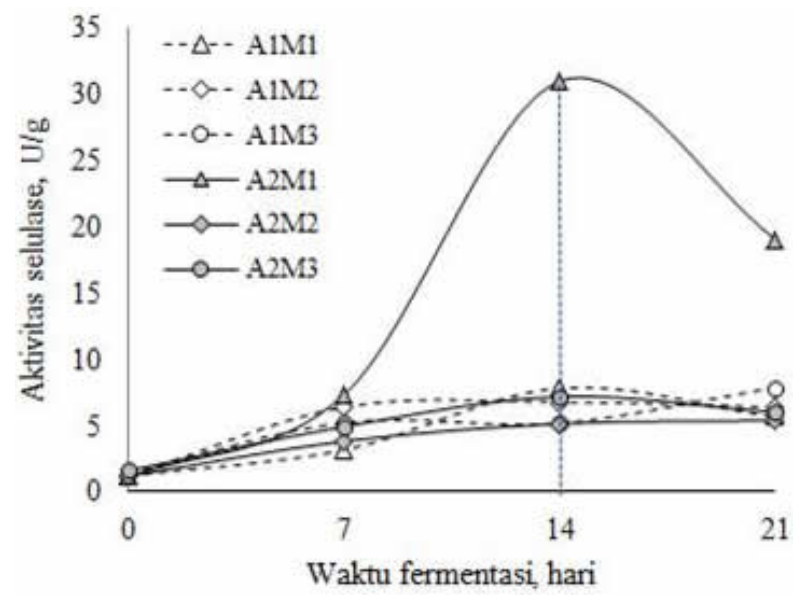

Gambar 5. Aktivitas selulase fungi A.niger $\mathrm{A}_{1}(0$ Gray) dan $\mathrm{A}_{2}$ (500 Gray) dalam substrat jerami dengan kadar kelembaban awal $M_{1}(81 \%), \quad M_{2}$ (84\%) dan $\mathrm{M}_{3}(87 \%)$ fermentasi padat substrat jerami padi $M_{1}$ (81\%) dengan fungi Aspergillus niger $\mathrm{A}_{2}$ selama 14 hari. Hasil ini selara dengan penelitian terdahulu yang menjelaskan bahwa aktivitas selulase fungi Aspergillus niger yang maksimum diperoleh pada 14 hari fermentasi padat [36].

Aktivitas selulase maksimum dari fungi Aspergillus niger $\mathrm{A}_{2}$ (500 Gray) dengan substrat jerami padi $M_{1}(81 \%)$ berpengaruh terhadap produksi glukosa yang optimal pada 14 hari fermentasi padat seperti disajikan pada Gambar 6. Aktivitas selulase maksimum dapat menghidrolisis selulosa secara optimal sehingga produksi gula mudah larut seperti glukosa yang juga maksimum [14]. Produksi glukosa pada medium fermentasi padat $\mathrm{A}_{2} \mathrm{M}_{1}$ ini sekitar $125,79 \mathrm{mg} / \mathrm{g}$ sedangkan pada medium lain $\left(\begin{array}{lllll}A_{1} M_{1}, & A_{1} M_{2} & A_{1} M_{3} & A_{2} M_{2} & A_{2} M_{3}\end{array}\right)$ sekitar $31,79 \mathrm{mg} / \mathrm{g}$ sampai $48,00 \mathrm{mg} / \mathrm{g}$ berat kering substrat jerami padi. Di dalam substrat jerami padi $\mathrm{M}_{1}$ dengan fungi Aspergillus niger $\mathrm{A}_{2}$ pada 7 dan 21 hari fermentasi padat diperoleh produksi glukosa sekitar 59,68 dan $107,81 \mathrm{mg} / \mathrm{g}$. Dengan demikian, produksi glukosa maksimal dapat diperoleh dari fermentasi padat substrat jerami padi $M_{1}$ dengan fungi Aspergillus niger $\mathrm{A}_{2}$ selama 14 hari. Hasil yang diperoleh setara dengan

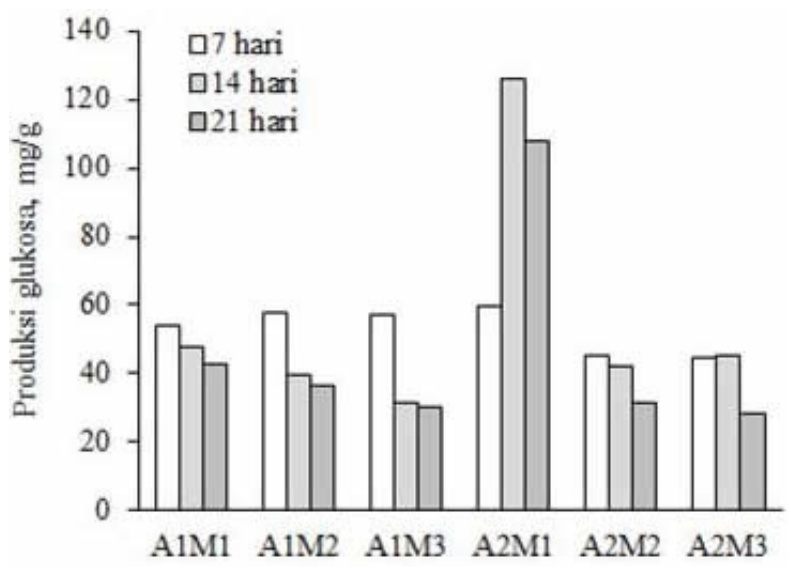

Gambar 6. Produksi glukosa pada fermentasi padat substrat jerami padi dengan kadar kelembaban awal $\mathrm{M}_{1}(81 \%)$, $\mathrm{M}_{2} \quad(84 \%)$ dan $\mathrm{M}_{3} \quad(87 \%)$ yang diinokulasi fungi A.niger $\mathrm{A}_{1}$ (0 Gray) dan $\mathrm{A}_{2}$ (500 Gray) 
penelitian terdahulu yang mendapatkan produksi glukosa optimal sebesar $175 \mathrm{U} / \mathrm{ml}$ [37].

Setelah 21 hari fermentasi padat, terjadi penurunan viabilitas fungi Aspergillus niger, aktivitas selulase dan produksi glukosa di dalam semua medium substrat jerami padi. Fermentasi padat substrat jerami padi $\mathrm{M}_{1}(81 \%)$ dengan fungi Aspergillus niger $\mathrm{A}_{2}$ (500 Gray) tetap menunjukkan aktivitas selulase dan produksi glukosa yang lebih tinggi dibandingkan fungi Aspergillus niger $\mathrm{A}_{1}$ (0 Gray) seperti disajikan pada Tabel 2. Aktivitas selulase fungi Aspergillus niger $\mathrm{A}_{1}$ dan $\mathrm{A}_{2}$ sekitar 5,92 dan 19,97 U/g dengan produksi glukosa masing-masing sekitar 42,59 dan 107,81 mg/g. Dengan demikian, inokulasi fungi Aspergillus niger yang dipapar sinar gamma 500 Gray dapat meningkatkan aktivitas selulase sekitar $237 \%$ dan produksi glukosa sekitar 153\%. Hasil ini menunjukkan bahwa fungi Aspergillus niger yang dipapar sinar gamma 500 Gray berpotensi untuk digunakan dalam meningkatkan aktivitas selulase dan produksi glukosa melalui fermentasi padat substrat jerami padi dengan kadar kelembaban awal sekitar $81 \%$.

Selain berpengaruh terhadap aktivitas selulase dan produksi glukosa, fermentasi padat selama 21 hari juga menyebabkan perubahan tumbuhan dan aktivitas fungi Aspergillus niger selama 21 hari fermentasi padat menyebabkan perubahan bobot biomassa mikroba, kadar bahan organik, C organik dan protein kasar di dalam substrat jerami padi seperti disajikan pada Tabel 1 . Perubahan bobot biomassa mikroba, bahan organik, $\mathrm{C}$ organik dan protein kasar terbaik diperoleh pada fermentasi padat substrat

Tabel 1. Peningkatan aktivitas selulase dan produksi glukosa pada fermentasi padat substrat jerami padi dengan Aspergillus niger selama 21 hari pada $28-32{ }^{\circ} \mathrm{C}$

\begin{tabular}{clccc}
\hline \multirow{2}{*}{ No } & \multirow{2}{*}{ Parameter } & \multicolumn{2}{c}{ Aspergillus niger } & \multirow{2}{*}{ Peningkatan } \\
\cline { 3 - 4 } & & 0 Gray & 500 Gray & \\
\hline 1 & Aktivitas selulase, U/g & $5,92 \pm 0,33$ & $19,97 \pm 6,38$ & $237 \%$ \\
2 & Produksi glukosa, mg/g & $42,59 \pm 20,29$ & $107,81 \pm 21,21$ & $153 \%$ \\
\hline
\end{tabular}

Tabel 2. Perubahan bobot biomassa fungi Aspergillus niger dan beberapa karakteristik fisik-kimia substrat jeremasi padi setelah 21 hari fermentasi pada $28-32{ }^{\circ} \mathrm{C}$

\begin{tabular}{cccccc}
\hline & & \multicolumn{4}{c}{ Perubahan, \% } \\
\cline { 3 - 6 } No & Perlakuan & $\begin{array}{c}\text { Biomassa } \\
\text { mikroba }\end{array}$ & $\begin{array}{c}\text { Bahan } \\
\text { organik }\end{array}$ & C organik & $\begin{array}{c}\text { Protein } \\
\text { kasar }\end{array}$ \\
\hline 1 & $\mathrm{~A}_{1} \mathrm{M}_{1}$ & 71,08 & 9,38 & 9,17 & 20,74 \\
2 & $\mathrm{~A}_{1} \mathrm{M}_{2}$ & 65,57 & 8,45 & 8,27 & 16,33 \\
3 & $\mathrm{~A}_{1} \mathrm{M}_{3}$ & 58,95 & 8,56 & 8,43 & 13,75 \\
4 & $\mathrm{~A}_{2} \mathrm{M}_{1}$ & 77,68 & 10,20 & 9,98 & 21,11 \\
5 & $\mathrm{~A}_{2} \mathrm{M}_{2}$ & 54,16 & 8,22 & 8,06 & 16,59 \\
6 & $\mathrm{~A}_{2} \mathrm{M}_{3}$ & 48,76 & 8,48 & 8,36 & 14,25 \\
\hline
\end{tabular}

Keterangan : fungi Aspergillus niger $\mathrm{A}_{1}$ (0 Gray) dan $\mathrm{A}_{2}$ (500 Gray), kadar kelembaban awal $\mathrm{M}_{1}(81 \%), \mathrm{M}_{2}(84 \%)$ dan $\mathrm{M}_{3}(87 \%)$. 
jerami padi $\mathrm{M}_{1}(81 \%)$ masing-masing 71,08 $77,68 \%, 9,38-10,20 \%, 9,17-9,98 \%$ dan $20,74-$ $21,11 \%$. Hasil ini menunjukkan bahwa kadar kelembaban awal substrat jerami padi sekitar $81 \%$ sesuai sebagai medium pertumbuhan fungi Aspergillus niger $\mathrm{A}_{1}(0$ Gray) dan $A_{2}$ (500 Gray). Kadar kelembaban yang terlalu tinggi di dalam medium padat dapat menurunkan porositas substrat dan menyebabkan penurunan penetrasi oksigen di antara partikel substrat sehingga terjadi penurunan pertumbuhan mikroba [38]. Kadar kelembaban berperan penting dalam biosintesis dan sekresi berbagai enzim termasuk enzim selulase [9].

Evaluasi pertumbuhan, aktivitas selulase dan produksi glukosa menunjukkan bahwa fungi Aspergillus niger yang dipapar sinar gamma 500 Gray berpotensi untuk digunakan dalam meningkatkan aktivitas selulase dan produksi glukosa melalui fermentasi padat substrat jerami padi dengan kadar kelembaban awal sekitar $81 \%$. Aktivitas selulase maksimum fungi Aspergillus niger ini diperoleh pada fermentasi padat substrat jerami padi selama 14 hari. jerami padi dengan fungi Aspergillus niger, dilakukan uji hidrolisis pada $50{ }^{\circ} \mathrm{C}$ selama 2 hari. Tabel 3 menunjukkan bahwa ekstrak enzim kasar dari perlakuan fermentasi padat yang berbeda berpengaruh terhadap kemampuan produksi dan hidrolisis glukosa dalam substrat jerami padi. Produksi dan hidrolisis glukosa yang tertinggi diperoleh pada pemberian ekstrak enzim kasar hasil 14 hari fermentasi padat substrat jerami $\mathrm{M}_{1}$ (81\%) dengan fungi Aspergillus niger $\mathrm{A}_{2}(500$ Gray). Hidrolisis substrat jerami padi dengan ekstrak enzim kasar ini menyebabkan produksi glukosa sekitar $35,84 \mathrm{mg} / \mathrm{g}$ dan hidrolisis glukosa sekitar $134,72 \mathrm{mg} / \mathrm{g}$ selulosa. Pada penggunaan ekstrak enzim kasar dari fermentasi padat substrat jerami $M_{1}(81 \%)$ dengan fungi Aspergillus niger $\mathrm{A}_{1}$ (0 Gray) diperoleh hasil yang lebih rendah, yaitu produksi glukosa sekitar $27,22 \mathrm{mg} / \mathrm{g}$ dan hidrolisis glukosa sekitar 102,29 mg/g selulosa. Hasil ini menunjukkan bahwa ekstrak enzim kasar dari fermentasi substrat jerami padi $M_{1}$ (81\%) dengan fungi Aspergillus niger $\mathrm{A}_{2}(500$ Gray) memiliki kemampuan hidrolisis substrat jerami padi terbaik.

Tabel 3. Produksi dan hidrolisis glukosa pada hidrolisis substrat jerami padi dengan ekstrak enzim kasar fungi Aspergillus niger pada $50{ }^{\circ} \mathrm{C}$ selama 2 hari

\begin{tabular}{ccccc}
\hline No & $\begin{array}{c}\text { Ekstrak enzim } \\
\text { kasar }\end{array}$ & $\begin{array}{c}\text { Produksi glukosa, } \\
\mathrm{mg} / \mathrm{g}\end{array}$ & $\begin{array}{c}\text { Hidrolisis glukosa, } \\
\mathrm{mg} / \mathrm{g} \text { selulosa }\end{array}$ & $\begin{array}{c}\text { Kadar glukosa, } \\
\mathrm{mg} / \mathrm{g}\end{array}$ \\
\hline 1 & $\mathrm{~A}_{1} \mathrm{M}_{1}$ & $27,22^{\mathrm{ab}}$ & $102,29^{\mathrm{c}}$ & $7,17^{\mathrm{a}}$ \\
2 & $\mathrm{~A}_{1} \mathrm{M}_{2}$ & $29,07^{\mathrm{b}}$ & $109,17^{\mathrm{b}}$ & $7,21^{\mathrm{a}}$ \\
3 & $\mathrm{~A}_{1} \mathrm{M}_{3}$ & $25,25^{\mathrm{ab}}$ & $94,83^{\mathrm{d}}$ & $9,19^{\mathrm{a}}$ \\
4 & $\mathrm{~A}_{2} \mathrm{M}_{1}$ & $35,84^{\mathrm{c}}$ & $134,72^{\mathrm{e}}$ & $20,22^{\mathrm{c}}$ \\
5 & $\mathrm{~A}_{2} \mathrm{M}_{2}$ & $23,73^{\mathrm{a}}$ & $89,12^{\mathrm{a}}$ & $15,54^{\mathrm{b}}$ \\
6 & $\mathrm{~A}_{2} \mathrm{M}_{3}$ & $26,51^{\mathrm{ab}}$ & $99,57^{\mathrm{c}}$ & $5,78^{\mathrm{a}}$ \\
\hline
\end{tabular}

Keterangan: fungi Aspergillus niger $\mathrm{A}_{1}\left(0\right.$ Gray) dan $\mathrm{A}_{2}$ (500 Gray), kadar kelembaban awal $\mathrm{M}_{1}(81 \%), \mathrm{M}_{2}(84 \%)$ dan $\mathrm{M}_{3}(87 \%)$.

\section{Efektivitas Ekstrak Enzim Kasar}

Untuk mengetahui kualitas enzim selulase hasil fermentasi padat substrat
Hidrolisis dengan ekstrak enzim kasar fungi Aspergillus niger berpengaruh terhadap peningkatan kadar glukosa dalam substrat 
jerami padi seperti disajikan pada Gambar 7 . Peningkatan kadar glukosa tertinggi diperoleh pada pemberian ekstrak enzim kasar dari fermentasi padat substrat jerami padi $M_{1}(81 \%)$ dengan fungi Aspergillus niger $\mathrm{A}_{2}$ (500 Gray). Setelah 2 hari hidrolisis pada $50{ }^{\circ} \mathrm{C}$, pemberian ekstrak enzim kasar $\mathrm{A}_{2} \mathrm{M}_{1}$ ini dapat meningkatkan kadar glukosa sekitar $188,24 \%$ dari 7,01 menjadi 20,22 $\mathrm{mg} / \mathrm{g}$ berat kering substrat jerami padi. Hasil ini selaras dengan efektivitas ekstrak enzim kasar terhadap produksi dan hidrolisis glukosa dalam substrat jerami padi.

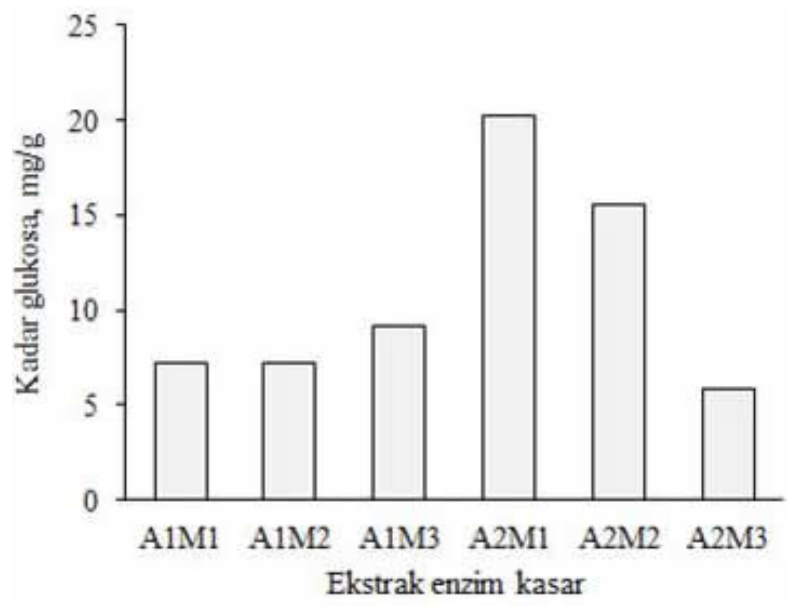

Gambar 7. Kadar glukosa substrat jerami padi setelah hidrolisis dengan ekstrak enzim kasar

Ekstrak enzim kasar dari fermentasi padat substrat jerami padi $\mathrm{M}_{1}(81 \%)$ dengan fungi Aspergillus niger $\mathrm{A}_{2} \quad(500$ Gray) memiliki kualitas yang lebih baik dibandingkan fungi Aspergillus niger $\mathrm{A}_{1}(0$ Gray). Hasil ini menunjukkan bahwa fungi Aspergillus niger yang dipapari sinar gamma 500 Gray sesuai untuk digunakan pada fermentasi substrat jerami padi dengan kadar kelembaban awal sekitar $81 \%$. Hasil juga mengindikasikan bahwa fermentasi padat substrat jerami padi selama 14 hari sesuai untuk produksi enzim selulase dengan aktivitas yang tinggi. Dengan demikian, peningkatan produksi enzim selulase dan kadar glukosa dapat dilakukan melalui fermentasi padat substrat jerami padi dengan kadar kelembaban awal sekitar $81 \%$ menggunakan fungi Aspergillus niger yang dipapari sinar gamma 500 Gray.

\section{KESIMPULAN}

Iradiasi gamma pada dosis 500 Gray sesuai untuk memperoleh fungi Aspergillus niger dengan aktivitas selulase yang lebih tinggi dibandingkan perlakuan lain $(0,125$, 250, 375, 625 Gray). Di dalam medium cair mengandung Potatoes Dextrose Broth (PDB), garam mineral dengan substrat jerami padi 0 dan $5 \% \mathrm{~b} / \mathrm{v}$, fungi Aspergillus niger yang dipapari sinar gamma 500 Gray memiliki aktivitas selulase sekitar 2,5 kali lebih tinggi dibanding kontrol yaitu 2,02-2,28 U/ml untuk fungi yang dipapari sinar gamma dan 0,60-1,12 U/ml untuk kontrol. Pada fermentasi padat substrat jerami padi dengan kadar kelembaban awal $81 \%$ selama 14 hari, fungi Aspergillus niger yang dipapar sinar gamma 500 Gray memiliki aktivitas selulase sekitar 3,91 kali lebih tinggi dibandingkan dibandingkan kontrol yaitu $31,01 \mathrm{U} / \mathrm{g}$ untuk fungi yang dipapari sinar gamma dan 7,85 U/g untuk kontrol. Pada aktivitas selulase maksimum ini diperoleh produksi glukosa 125,79 dan 48,00 mg/g. Hasil ini menunjukkan bahwa pada fermentasi padat jerami padi dengan fungi Aspergillus niger yang dipapari sinar gamma 500 Gray dapat diperoleh produksi glukosa sekitar 2,62 kali lebih tinggi dibandingkan fungi Aspergillus niger tanpa perlakuan iradiasi gamma. Penggunaan ekstrak enzim kasar dari fermentasi padat dengan fungi Aspergillus niger yang dipapar sinar gamma 500 Gray sesuai untuk hidrolisis substrat jerami padi. Dengan demikian, fungi Aspergillus niger yang dipapari sinar gamma 500 Gray memiliki potensi yang baik dalam meningkatkan aktivitas selulase dan produksi glukosa dalam substrat jerami padi melalui fermentasi padat selama 14 hari. 


\section{UCAPAN TERIMA KASIH}

Penulis mengucapkan terima kasih kepada Ibu Ayi Ratnaningsih, S.Si,M.Si (Universitas Nusa Bangsa, Bogor) atas bantuan teknis selama penelitian ini berlangsung.

\section{DAFTAR PUSTAKA}

1. FAN, F.T., M.M. GHARPURAY and Y. N. LEE, Cellulose Hydrolysis, Springer-Verlag 3, 1-68 (1987).

2. SOLOMON, B.O., B. AMIGUN, E. BETIKU, T.V. OJUMU and S.K. LAYOKUN, Optimization of cellulase production by Aspergillus flavus Linn Isolate NSPR101 Grown on Bagasse, JNSCHE, 16, 61-68 (1999).

3. KUMAKURA, M., Preparation of immobilized cellulase beads and their application to hydrolysis of cellulose materials, Process Biochem. 32, 555-559 (1997).

4. OGEL, Z.B., K. YARANGUMELI, H. DURDAR I. IFRIJ, Submerged cultivation of Scytalidium thermophilum on complex lignocellulosic biomass for endoglucanase production, Enzyme Microbial. Technol., 28, 689-695 (2001).

5. ABO-STATE, M.A.M., A.I. HAMMAD, M. SWELIM and R.B. GANNAM, Enhanced Production of Cellulase(S) By Aspergillus spp. Isolated From Agriculture Wastes by Solid State Fermentation, American Eurasian J. Agric. Environ. Sci., 8 (4), 402-410 (2010).

6. ANITA, S., S. NAMITA, R. NARSI and BISHNOI, Production of cellulases by Aspergillus heteromorphus from wheat straw under submerged fermentation, Int. J. Environ. Sci. Eng., 1, 23-26 (2009).

7. SUKUMARAN, R.K., R.R. SINGHANIA, G.M. MATHEW and A. PANDEY, Cellulase production using biomass feed stock and its application in lignocellulose saccharification for bio-ethanol production, Renewable Energy., 34, 421-424 (2009).

8. XU, F., J. WANG, S. CHEN, W. QIN, Z. YU, H. ZHAO, X. XING and H. LI, Strain Improvement for Enhanced Production of Cellulase in Trichoderma viride, Appl. Biochem. Microbiol., 47 (1), 53-58 (2011).

9. VU, V.H., T.A. PHAM and K. KIM, Improvement of Fungal Cellulase Production by Mutation and Optimization of Solid State Fermentation, Mycobiology, 39 (1), 20-25 (2011).

10. MANDELS, M. and E.T. REESE, Fungal cellulase and microbial decomposition of cellulosic fibres, Dev. Ind. Microbiol., 5, 5-20 (1985).

11. SARAO, L.K., M. ARORA and V.K. SEHGAL, Use of Scopulariopsis acremonium for the production of cellulose and xylanase through submerged fermentation, Afr. J. Microbiol. Res., 4 (14), 1506-1510 (2010).

12. IMMANUAL, G., R. DHANUSHA, P. PRENA and PALAVESAN, Effect of different growth parameters on endoglucanase enzyme activity by bacteria isolated from coir retting effluents of estuarine environment, Int. J. Environ. Sci. Tech., 3 (1), 2534 (2006).

13. BAKRI, Y.P., P. JACQUES and THONAR, Xylanase production by 
Penicillum canescens $10-10 \mathrm{c}$ in solid state fermentation, Appl. Biochem. Biotechnol., 108 (1-3), 737-748 (2003).

14. DEVI, M.C. and M.S. KUMAR, Production, Optimization and Partial purification of Cellulase by Aspergillus niger fermented with paper and timber sawmill industrial wastes, J. Microbiol. Biotech. Res., 2012, 2 (1), 120-128 (2012).

15. MRUDULA, S. and R. MURUGAMMAL, Production of Cellulase by Aspergillus niger under Submerged and Solid State Fermentation using Coir Waste as a Substrate, Brazilian Journal of Microbiology, 42, 1119-1127 ISSN 1517-8382 (2011).

16. GHILDYAL, N.P., B.K. LONSANE, K.R. SREEKANTIAH and V.S. MURTHY, Economics of submerged and solid state fermentation for the production of amyloglucosidase, J. Food Sci. Technol., 22, 171-176 (1985).

17. YANG, Y.H., B.C. WANG, Q.H. WANG, L.J. XIANG and C.R. DUAN, Research on solid-state fermentation on rice chaff with a microbial consortium, Colloid Surf., 34, 1-6 (2004).

18. SINGHANIA， R.R., A.K. PATEL, C.R. SOCCOL and A. PANDEY, Recent advances in solid-state fermentation, Biochem. Eng. J., 44, 13-18 (2009).

19. LI, X.H., H.J. YANG, B. ROY, E.Y. PARK, L.J. JIANG, D. WANG and Y.G. MIAO, Enhanced cellulose production of the Trichoderma viride mutated by microwave and ultraviolet. Microbiol. Res., 164 (1), 81-91 (2009).
20. FAWZI, E.M. and H.S. HAMDY, Improvement of carboxymethyl cellulase production from Chaetomium cellulolyticum NRRL 18756 by mutation and optimization of solid state fermentation, African Journal of Microbiology Research, 5 (26), 4687-4696 (2011).

21. VRIES, R.P. and J. VISER, Aspergillus enzymes involved in degradation of plant cell wall polysaccharides, Microbiol. Mol. Biol. Rev., 65, 497552 (2001).

22. NALLAPETA, S., V. K. NIGAM, P. SURVAJAHALA and K. MOHAN, Screening and Selection of White Rot Fungi for Biological Delignification of Agricultural Residues, International Journal of Advanced Biotechnology and Research 3 (4), 790-796 (2012).

23. ONG, L. G. A., C.H. Chan and A.L. CHEW, Enzymatic Hydrolysis of Rice Straw: Process Optimization, Journal of Medical and Bioengineering (JOMB), 1 (1), 14-16 (2012).

24. PENSUPA, N., M. JIN, M. KOKOLSKI, D. B. ARCHER and C. DU, A solid state fungal fermentation-based strategy for the hydrolysis of wheat straw, Bioresource Technology, 149, 261-267 (2013).

25. MANPREET, S., S. SAWRAJ, D. SACHIN, S. PANKAJ, S. and U.C. BANERJEE, Review Article : Influence of Process Parameters on the Production of Metabolites in Solid-State Fermentation, Malaysian Journal of Microbiology, 1 (2), 1-9 (2005).

26. SARASWATI, R., E. HUSEN dan R.D.M SIMANUNGKALIT, Metode Analisis Biologi Tanah, Halaman 1018, ISBN: 978-602-8039-05-5, Balai 
Besar Penelitian dan Pengembangan, Sumberdaya Lahan Pertanian (2007).

27. HAMZAH, AINON, M.A. ZARIN and A.A. HAMID, Optimal Physical and Nutrient Parameters for Growth of Trichoderma virens UKMP-1M for Heavy Crude Oil Degradation, Sains Malaysiana, 41 (1), 71-79 (2012).

28. FADEL, M., T. KAHIL and S.M. ABDEL-AZIZ, Farm Scaling up Biological Treatment by Solid State Fermentation to Invest Rice Straw as a Livestock Feed in Egypt, Journal of Basic and Applied Scientific Research, 3 (12), 258-263, ISSN 2090-4304 (2013).

29. MASUTTI, D.C., A. BORGOGNONE and L. SETTI, Production of Enzymes from Rice Husks and WheatStraw in Solid State Fermentation, Chemical Engineering Transaction, 27, 133-138, ISBN 97888-95608-18-1; ISSN 1974-9791 (2012).

30. DEWI, C., T. PURWOKO dan A. PANGASTUTI, Produksi Gula Reduksi oleh Rhizopus oryzae dari Substrat Bekatul, Bioteknologi, 2 (1), 21-26 (2005).

31. MOUSSA, T.A.A and M.A. RIZK, Impact of Gamma Irradiation Stresses : Control of Sugarbeet Pathogens Rhizoctonia solani Kuhn and Sclerotium rolfsii Sacc., Pakistan Journal of Plant Pathology, 2 (1), 10-20 (2003).

32. YOUNIS, N.A., A comparison study on protease, alpha-amylase and growth of certain fungal strains of Aspergillus sp. after exposure to gamma-rays, Arab Journal of Nuclear Sciences and Applications, 32 (2), 257-264 (1999).

33. ALTING, S.A., ZHONG,Z.P. and DENG, X.Q., Enhanced cellulose production by gamma-ray induced mutant of Aspergillus niger CICC41125 on agro wastes, Journal of Zheijang University-SCIENCE B(Biomedicine \& Biotechnology), Springer-Verlag Berlin Heidelberg, 1-14 (2015).

34. GHERBAWY, Y.A., Effect of gamma irradiation on the production of cell wall degrading enzymes by Aspergillus niger, International Journal of Food Microbiology, 40, 127-131 (1998).

35. CHAKRAVARTY, B. and S. SEN, Enhancement of regeneration potential and variability by gammairradiation in cultured cells of Scillaindica, Biol. Plant., 44, 189-193 (2011).

36. UTHARALAKSHMI, $\mathrm{N}$ and A.G. KUMAR, Production of Cellulase by Aspergillus Sp.Under Solid State Fermentation, International Journal of Chem. Tech. Research, 6 (12), 5142-5145 (2014).

37. MUHAMMAD, A.Z., SAMREEN, R. and TEHREEMA, I., Effect of gamma irradiation on Aspergillus niger for enhanced production of glucose oxidase, Pakistan J. Bot., 44 (5), 1575-1580 (2012).

38. SINGHANIA, R.R., A.K. PATEL, C.R. SOCCOL and A. PANDEY, Recent advances in solid-state fermentation, Biochem. Eng. J., 44, 13-18 (2009). 
Jurnal Ilmiah Aplikasi Isotop dan Radiasi

A Scientific Journal for The Applications of Isotopes and Radiation

ISSN 1907-0322

Vol. 11 No. 1 Juni 2015 